\title{
VARIANCES IN CONSUMERS PRICES OF SELECTED FOOD ITEMS AMONG MARKETS IN CROSS RIVER STATE
}

\author{
S. B. AKPAN AND E. A. AYA
}

(Received 8, August 2009; Revision Accepted 4, October 2009)

\begin{abstract}
The study focused on the determination of variances among consumer prices of rice (local white), beans (white) and garri (yellow) in Watts, Okurikang and 8 Miles markets in southern zone of Cross River State. Completely randomized design was used to test the research hypothesis. Comparing the consumer prices of rice, beans and garri in the three markets; rice and garri had insignificant differences in their consumer prices while beans consumer prices had significant differences between Okurikang market and the other two markets. The results imply perfect information flow in garri and rice markets and hence high possibility of a perfectly competitive market structure for these products. The reverse is the case for beans market. Policies on increased local production of rice, garri and beans as well as improved marketing infrastructures were recommended as these would help increase sellers profit while maximizing consumers' benefits.
\end{abstract}

KEY WORDS: price, market, consumer, garri, rice, beans.

\section{INTRODUCTION}

Agricultural production plays an important role in economic development of Nigeria. An estimated $60 \%$ of Nigerians live in the rural areas and majority are engaged in small scale agricultural production (Okunneye, 2003). Over the past years, the market for agricultural commodities has shown a pattern of long- term price fall and short-term price instability (IMF, 2000). The volatility in price of agricultural commodities in Nigeria has been attributed to various factors including variances in bargaining power among consumers, cyclical income fluctuations among sellers and consumers, natural shocks such as flood, pests, diseases, and inappropriate response by farmers to price signals (Gilberts, 1999, Udoh et al 2007, Adebusuyi, 2004).

Short- run fluctuations in agricultural commodity prices occur between production seasons (Cashin and Pattillo, 2000). During the harvesting period, farmers offer to the market the minimum price for their products. In the offseason, prices become high due to reduced production and seasonal changes (Akpan, 2002).
Within this period the quantity of commodities supplied by farmers and demanded by consumers are mostly determined by price. For an individual commodity, the changes in nonprice related factors cause instability in the price of the product. Product price instability among agricultural commodities is a regular phenomenon in markets across Nigeria (Akpan, 2007). Instability in commodity prices among markets could be detrimental to the marketing system and the economy as a whole. It could cause inefficiency in resource allocation among sellers and consumers depending on the source of variability (that is whether it is induced by supply or demand side or both). It could also increase poverty level among low income earners in the society (Polaski, 2008). On the order hand, a unified product price among markets is not a rational policy to pursue in a developing country like Nigeria. This is because of the deteriorating marketing infrastructures which often resulted in significant differences in the total variable costs incurred by sellers in the markets.

Rice (local white), garri (yellow) and beans (white) are among staple food items whose prices are highly unstable between

\section{S. B. Akpan, Department of Agricultural Economics, Michael Okpara University of Agriculture, Umudike, Abia State}

E. A. Aya, Department of Agricultural Economics, University of Uyo, Uyo Akwa-lbom State. 
seasons in Cross River State. Consumers pay different amounts for the same product in different markets separated by few kilometers. Price instability of agricultural commodity would be considered a normal phenomenon if it does not significantly differ from one market to another. On the contrary, if products prices are significantly different among markets it may distort resources flow and may also likely negate some objectives of the governments. Following these anticipated problems, the important question is: Are staple food commodity prices statistically different among markets in Cross River State? In an attempt to answer this question, the study sought to determine whether there are statistical significant differences in variances in consumers' prices of rice, garri and beans among selected markets in the study area.

\section{Significance of the Study}

The result of the study will serve as a useful guide to policy makers to effectively formulate commodity price related policies in the state. Government would also find the study useful as it would reveals some constraints militating against smooth commodity market operations in the state. In addition students and economic analysts would find the study valuable, as it would be a guide to other related studies and a relevant source of information.

\section{MATERIALS AND METHODS}

The study was conducted in the southern part of Cross River State. Three local government areas were randomly selected; these were Calabar Municipality, Calabar South and Odukpani local government areas. One market in each selected local government area was purposefully picked for data collection. The markets were: Watts market in Calabar south, 8 miles market in Calabar municipality and Okurikang market in Odukpani local government areas. The choice of the markets was based on their relative sizes, location and their similarities in marketing functions with other markets in the zone. Three staple food items were used for the analysis and these were rice (local), beans and garri (yellow). Sixty sellers of each of this food items were used for data collection. Twenty sellers of each of these food items were randomly picked from Watts, 8 Miles and Okurikang markets. Primary data collected included prices of garri; beans and rice measured in $7 \mathrm{~cm}$ cup.

\section{RESEARCH DESIGN}

Analysis of variance technique was employed to test the null hypothesis. Under this, completely randomized design method was used to estimate F- calculated. Mathematically, the model is stated below.

$\mathrm{Y}_{\mathrm{ij}}=\mu+\mathrm{T}_{\mathrm{i}}+\mathrm{e}_{\mathrm{i}}$

Where $Y_{i j}=$ Single observation (seller), $\mu=$ Population mean, $T_{i}=$ Treatment effect (average weekly price of garri, beans and rice), $\mathrm{e}_{\mathrm{ij}}=$ error term $\left(\mathrm{e}_{\mathrm{ij}} \sim \operatorname{IIN}\left(0, \delta^{2}\right)\right.$.

\section{HYPOTHESIS}

Ho: There are no significant differences in consumers' prices of garri, beans and rice among markets in Cross River State.

\section{RESULTS AND DISCUSSION}

\section{(a) COMPARING PRICES OF GARRI IN WATTS, 8 MILES AND OKURIKANG MARKETS.}

\begin{tabular}{lccccc} 
& \multicolumn{4}{c}{ ANOVA (Garri) } \\
Source of variability & d.f & SS & MS & F-cal & Sig \\
Treatment & 2 & 6.201 & 3.101 & 2.273 & 0.113 \\
Error & 51 & 69.568 & 1.364 & & \\
Total & 53 & 75.769 & &
\end{tabular}

F-calculated is not significant at $1 \%, 5 \%$ and $10 \%$ hence we accept the null hypothesis. The implication is that there are no significant differences among prices of garri in the selected markets. Since the prices of garri in the three markets are not significantly different, there is high probability of good information flows among the sellers and buyers of garri in the Study area. There are likely large number of buyers and sellers, similar market charges and probably good level of garri market integration in the zone. The statistical equality of consumers' price of garri in the three markets shows good trace of marketing efficiency of the product in the zone. Therefore, the result suggests possible existence of perfect competitive market structure for garri in the study area. 
(b) COMPARING PRICES OF BEANS IN WATTS, 8 MILES AND OKURIKANG MARKETS.

\begin{tabular}{lccccc} 
& \multicolumn{5}{c}{ ANOVA (Beans) } \\
Source of variability & d.f & SS & MS & F-cal & Sig \\
Treatment & 2 & 178.903 & 89.451 & 3.350 & 0.043 \\
Error & 51 & 1361.981 & 26.706 & & \\
Total & 53 & 1540.884 & &
\end{tabular}

F-calculated is significant at $5 \%$ level, thus we reject the null hypothesis at $5 \%$ significance level. This means that there are significant differences in prices of beans among sellers in the selected markets. Using least significant differences to separate the mean consumer prices of beans in the three markets, it was observed that the consumer prices of beans in Watts and 8 Miles markets were not significantly different. However, there are

significant differences in consumer price of beans between Okurikang market and the other two markets. The occurrence of significant variances in consumer price of beans in some markets confirmed the inconsistency in costs incurred and returns that accrued to the sellers of these products. The result is an indication of poor information transmission among the consumers and sellers of beans commodity across the markets in the zone.

\section{(c) COMPARING PRICES OF RICE IN WATTS, 8 MILES AND OKURIKANG MARKETS.}

\begin{tabular}{lccccc} 
& \multicolumn{5}{c}{ ANOVA (Rice) } \\
Source of variability & d.f & SS & MS & F-cal & Sig \\
Treatment & 2 & 21.934 & 10.967 & 0.256 & 0.776 \\
Error & 51 & 2189.074 & 42.923 & & \\
Total & 53 & 2211.010 & & &
\end{tabular}

F-calculated is not significantly different from zero at $5 \%, 10 \%$ and $1 \%$ levels respectively. Therefore we accept the null hypothesis. This implies that there are no significant differences among consumer prices of rice in the selected markets. The likely causes of above result for rice market are similar to that of garri market. A large proportion of local rice consumed in the zone is produced in the state. Thus transportation cost is reduced compared to beans market. Hence a perfectly competitive market structure is also suspected for rice market in the zone.

\section{CONCLUSION AND POLICY IMPLICATION}

The findings revealed that consumers' prices did not significantly differ for garri and rice markets in the zone. These imply good information flow among markets and consistent market policies with regard to garri and rice markets in the study area. The occurrence of statistical significant differences in prices of beans among markets in the zone is as a result of marketing inefficiencies with regards to beans market. Marketing infrastructures such as good road network, storage facilities, subsidized transportation facilities and modern publicity

channels should be upgraded to reduce cost on the part of the sellers while optimizing consumers benefit through lower prices. Also local production of garri, beans and rice should be boosted through input subsides. On a short-run basis, incentives in form of free market charges would be useful to beans marketers as this would reduce consumer price gap across markets in the zone.

\section{REFERENCES}

Adebusuyi, B. S., 2004. Stabilization of commodity market of interest to Africa: Paper presented at the workshop on constraints to growth in sub-Saharan Africa, held in Pretoria South Africa.

Akpan, S. B., 2002. Analysis of Gross Margin Efficiency of rice beans and garri in Selected markets in Cross River State. Unpublished undergraduate project work. UNICAL.

Akpan, S. B., 2007. Relative Price Variability and Inflation: A case study of Grain subsector in Nigeria. Unpublished Mas Degree Thesis. University of Uyo. 
Cashin, P. and Pattillo, C., 2000, 'Terms of trade shocks in Africa: Are they short-lived or long-lived? IMF Working Paper. Washington, DC: IMF.

Gilbert, C., 1999. Commodity risk management for developing countries: paper prepared for the third meeting of the international task force (ITF) held in Geneva 23-24 June 1999.

IMF., 2000. World Economic outlook, Washington DC: International Monetary Fund.

Okoh, R and Egbon, P., 2002. A Test of markets integration: The case of Nigerian staple food stuffs. African Economic Research Consortium Report 9, (2): Dec. 2002.
Okunneye, P. A., 2003. Rising cost of food prices and food insecurity in Nigeria and its implication for poverty reduction. CBN Economic and Financial Review, 39(4): 23-38.

Polaski, S., 2008. Rising Food Prices, Poverty and Doha Round. Carnegie endowment for international Peace.

Udoh, E. J., and Sunday B. A., 2007. Estimating Exportable Tree Crop Relative Price Variability and Inflation Movement under different Policy Regimes in Nigeria. European Journal of social Science. 5(2): 17-26. 